UDC 94(479.25):316:32

Ashot VOSKANIAN

\title{
ON TWO FACTORS OF NATIONAL IDENTITY: ORIENTATION AND SOCIAL STRUCTURE OF SOCIETY
}

\begin{abstract}
Given peculiarity of Armenian history, the Armenian political thought for centuries debated around geopolitical orientation between neighboring great powers. In post-Soviet reflections, however, the emphasis has been moved towards self-reliance, and the very principle of political orientation was questioned. The attitude towards Israel Ori, whose name was viewed as a symbol of the principle of orientation, became the locums for determining the political-ideological disposition of debater, as well as understanding their approaches towards different concepts of national identity.

A brief comparison between the conceptual paradigms of two renowned historians Ashot Hovhannisyan (1887-1972) and Leo (Arakel Babakhanyan, 1860-1932) in relation to their attitude towards Israel Ori aims to demonstrate that questioning of the very principle of orientation has much deeper roots in Armenian historical studies than commonly is believed. It also illuminates the complex relationship between principle of orientation and desired model of social structure of society, which these two classics have revealed in rather different ways.
\end{abstract}

Keywords: national identity, geopolitical orientation, social structure, methodology of historical studies, Israel Ori, Leo, Ashot Hovhannisyan.

I

Shortly after the collapse of Soviet Empire, a critical re-examination of conventional perceptions about national identity surfaced in Armenia. One of the key issues around which the debate revolved was the question of geopolitical orientation. Due to peculiarity of Armenian history, the Armenian political thought for centuries debated around orientation between neighboring great powers: whether Rome or Parthia, Byzantine Empire or Persia, whether Turkey or Russia. The distinctive feature of the post-Soviet debates, however, was that any mode of political ori- entation was viewed as vulnerable and the very principle of political orientation was questioned. The emphasis moved towards the principle of self-reliance, according to which any conflict with neighboring countries should be resolved on their own - stipulated in "the law of excluding the third force". 1

1 The doctrine suggested by Armenian historian and philologist Rafael Ishkanyan (belongs to a narrow circle of the Karabakh Committee) argued that Armenia should rely only on itself for resolving its issues with the neighbors and its foreign policy should be therefore limited only to doable tasks (Ishkhanian 1991). 
During these ideological debates the evaluation of the role of Israel Ori came to full strength. The name of this famous Armenian diplomat and political activist of $17^{\text {th }}$ century was rightfully viewed as a symbol of the principle of orientation. The attitude towards Israel Ori's political thinking became the locums for determining political-ideological disposition of the debater, as well as for understanding their approaches towards different concepts of national identity.

In the following years after the independence the debate didn't go on and was actually forgotten. As well, the linkage between the principle of orientation and other, especially social components of national identity was ignored.

\section{II}

The paper intends to demonstrate, that the questioning of the very principle of orientation has deeper roots in Armenian historical studies than commonly is believed. At the same time, I want to show the direct relationship, existing between the principle of orientation, which primarily related to the external factors that shape identity, and the problems of social structure of society, which are obviously connected to the internal self-organization of national body.

Hence, I will make a brief comparison between two "Great Shushi people" - historians Ashot Hovhannisyan and Leo (Arakel Babakhanyan). I will review their conceptual paradigms in relation to the attitude towards Israel Ori and his idea of "liberating Armenia with the help of foreigners". I hope, that the reflection of historical studies of these two prominent scholars will help to illuminate the complex relationship between 'the principle of orientation' and the social structure of society, which they have shown in rather different ways.

\section{III}

Ashot Hovhannisyan (1887-1972) has confessed in his thesis "Israel Ori and the idea of Armenian national liberation" (Johannissjan, 2016) that the interest in the topic was fueled by the assessment of his teacher, Professor Karl-Theodor von Heigel, according to which Israel Ori was an adventurist pursuing his personal interest (Johannissjan, 2016, p. 416). Hence, A. Hovhannisyan wanted to demonstrate that Ori's "adventurism" had a historical justification, because it has fostered the development of the Armenian aspirations for national liberation.

It must be noted that A. Hovhannisyan wasn't a proponent of the idea of "liberating Armenia with the help of foreign powers". As a Marxist-historian he underlined the common social struggle of the Armenians and other exploited neighboring nations, which in the end should have resulted into liberation. At the same time, being a pragmatic historian, he accepted that such ideas had played significant role in Armenian history. He saw the source of "the Armenian liberation legend" in the dream ascribed to Armenian Katholicos Nerses the Great, which predicted that the Armenian liberation (salvation) would take

2 Defended at Ludwig Maximilian University of Munich in 1913. The main ideas of this work were further developed in the two-volume monograph "Episodes in the History of Armenian Liberation Thought" (Hovhannisyan, 1957, 1959). 
place by Byzantine support. Over the centuries, the legend has metamorphosed several times, but the core idea of the external salvation has remained intact.

The objective of A. Hovhannisyan was to demonstrate that all historical phases of external liberation idea have been propelled by certain class' or social layer's interest. In this way, a nexus between the process of social and national liberation has been established. From this very perspective was analyzed also the shift from Western orientation to Russian one, implemented due to Israel Ori's activities. The real value behind Russian orientation was that thanks to it, Armenians were eventually integrated into new community regulated by Soviet ethos. This switch from the national perspective to the social one has kept in mind another "specific-Marxist"3 Alexander Miasnikian saying "from all orientations the Soviet one is the best".

However, if interpreted in this light, the principle of orientation in its conventional sense is surmounted. The Armenian liberation legend having originated from national liberation ideology transforms into social liberation reality.

It is not hard to notice that A. Hovhannissian's presentation of historical events has been fashioned as a "grand narrative" in terms of J-F. Lyotard. The essential historical episodes are described and assessed from actual perspective of narrator, who knows the end of story. It is understood that A. Hovhannisyan being a cognizant historian didn't suppose that there were direct cause and effect rela-

3 Group of Armenian Marxists (similar to the Jewish "Bund"), which tried to combine the ideology of social liberation with "specific" features of Armenian national identity. tionship between Armenian liberation dreams and historical process conditioned by real economic and social interests. Nevertheless, he thought that in Armenia, which has desperately lagged behind global developments, the ideas, dreams and even delusions about liberation turned into the base for social mobilization; hence they were instrumental in creating new social reality. In that very point Hovhannisyan has noted the positive side of the adventurist activities of Israel Ori as termed by his teacher Prof. Heigel.

Within the same context we should assess A. Hovhannissian's ambivalent approach towards the falsifications in history. To wit, he demonstrates that Israel Ori and his confederate Father Minas have falsified the reality for Peter the Great, trying to convince him that Armenians have always been of Russian orientation. Hovhannisyan believes that the fake letter, presenting something as reality, which in fact didn't even exist, has given an impulse for creating a new historical perspective.

It is noteworthy, that the same fact uncovered by A. Hovhannisyan provoked the second hero of this paper - historian Leo, to review his positive assessment of Israel Ori in his earlier works. Some scholars believe that Leo's change of attitude towards Israel Ori had moralistic grounds. I think there were other reasons. In order to persuade them, let us turn to Leo's concept of historical study.

\section{IV}

Leo's (1860-1832) most popular work the three-volume "Armenian History" (the first volume published in 1919), was written in opposition to the academic school of Ar- 
menian historiography. Leo consciously apposed himself to the conventional Armenian historians, in trying to inject emotional, "vivid" elements in his studies thus orienting his work towards more patriotic, ideological dimension.

The tragic experience of Armenian Genocide turned into a powerful impulse resulting into U-turn at second stage of Leo's work, which can be understood as self-overcoming, if not self-denial.

Leo of later period becomes a ruthless critic of the liberation project, linked with external support. I believe, that the shift of his attitude towards Israel Ori was not necessarily connected to morality issue, but conditioned much more by a conviction that fake ideas that do not reflect the reality in a proper way push for adventurist and irresponsible actions, leading to consequences, which can be disastrous for the whole nation.

Hence, we can say that our two proponents had concentrated on different constituencies of ideology (in sense of Karl Mannheim). Hovhannisyan tries to explicate utopian element of the idea of national liberation, while treating it as a kind of futuristic vision. Leo understands the ideology of national liberation as a collection of delusions, as "false consciousness" in sense of the Frankfurt School. Therefore, we can consider the second stage of Leo's work as a critique of ideology.

This concept has emerged from Leo's work "The Ideology of Turkish-Armenian Revolution", written in 1928, published in 1934 in Paris (Leo, 1994). Here Leo demonstrates the clear nexus between TurkishArmenian liberation ideology and the principles of Russian socialism, in particular with the ideology of "narodniki" and that of M. Bakunin. As a figure who has transmitted those ideas to the Armenian ground, he has considered Mikael Nalbandian - a publicist, poet and political activist, to whom, by the way, Ashot Hovhannisyan has dedicated his second fundamental monograph (Hovhannisyan, 1955, 1956).

The weak point of Nalbandian's liberation project Leo sees in the contradiction between social and national ways of liberation. This important problem has been codified in Nalbandian's classical article "Agriculture as a direct Way" written in 1862 (Nalbandian, 1985). The willful postponement of the social component of liberation project and limitation of national liberation to Western Armenia only (Leo noted that in fact Nalbandian had no idea of real situation there) has rendered his liberation project to being abstract and adventurist one.

That adventurism for the sake of success of the endeavor, has especially exhibited itself in one episode, which in fact repeats - although unsuccessful - the story of Israel Ori's fake letter. In order to mobilize the Armenian community, Nalbandian has attempted to persuade Istanbul-Armenian Serovbe Tagvoryan to spread news that there is an active underground secret committee in the city. The request was turned down on grounds that it would discredit the movement.

Leo's methodological idea of orientation as false consciousness was further developed in his book "Khojas' (Merchants) Capital" (Leo, 1934). It was transformed to the concept of "clerical diplomacy" and applied on all of Armenian history. When this specific form of diplomatic activities, based on class interest of the clergy and inalienably chained with re- 
ligious principles, dogmas and beliefs, transcends into secular realm it turns into an unrealistic policy guided with abstract ideas ${ }^{4}$.

It is easy to see, that Leo's 'Khojas' Capital" - like Hovhannisyan's monograph - is constructed in "grand narrative" fashion. However, unlike A. Hovhannisyan, who presents a sequence of ripening liberation ideas, Leo qualifies the same chain of historical events as a rally of starry-eyed and destructive delusions ${ }^{5}$.

\section{V}

This principled opposition is explained by the difference of the respective perspectives of two historians. A. Hovhannisyan views Armenian history from resurrected Soviet Armenia, which marches towards the future. Leo's perspective, in contrary, streams from the tragic experience of Armenian Catastrophe.

Notwithstanding the considerable differences, there is significant degree of similarity in the concepts of these authors. The most

4 It would be of scientific interest to compare the Leo's "clerical diplomacy" with the" protestant diplomacy", which, according to some scholars has defined the policy of US president W. Wilson towards the victims of Armenian Genocide. For more accounts see (Grabill 1974).

5 Do not be amiss to notice that in order to create a general impression of holistic historical perspective the both historians tried to avoid forms of continuous linear narrative and preferred to work with large "episodes". This specific fact is reflected in the titles of their masterpieces: "Episodes in the History of Armenian Liberation Thought" and "Episodes from Armenian Clerical Diplomacy" (covering heading for "Khoja's Capital") by Leo. important common feature was the interest towards the social dimensions of history. Ashot Hovhannisyan has shown how the question of geopolitical orientation was transformed into the question of choosing a preferable social model. In Leo's work there was a key shift of research focus towards studying the economic relations, first of all the international movement of the Armenian trade capital, which, as he believed, had enormously influenced the national history. Moreover, cooperation as well as competition of Armenian merchants with East Indian Company came to signify the Armenian participation in shaping a new economic world order. In this regards, Leo follows the footsteps of Professor M. Pokrovski and alongside the latter, he can be viewed as forerunner of the "worldsystem" theory.

Thus, the analysis of different methodological traditions in historical studies unveils that the correlation between geopolitical orientation (the essential component of national liberation ideology) and the models of social organization of national life - is rather complicated and is often functioning on implicit levels. This hidden linkage is an important factor, which influences further transformations of national identity. This is yet another reason for scholars who are interested in Armenian identity to direct their researches towards understanding nonlinear relations between desirable ("ideal") and existent ("real") forms of social organization in Armenia.

\section{REFERENCES}

Grabill, J. (1974). Protestant Diplomacy and an American Mandate for Armenia: 1914-1920, In: Recent Studies in Mo- 
dern Armenian History. Armenian Heritage Press. Cambridge, Mass.

Hovhannisyan, A. (1955, 1956). Nalbandyany' \& nra jhamanaky' (Nalbandyan and his Time, in Armenian). Vol. $1 \& 2$. Yerevan: Haypethrat.

Hovhannisyan, A. (1957, 1959). Drvagner hay azatagrakan mtqi patmut'yunic (Episodes from the History of Armenian Liberation Thought, in Armenian). Vol. $1 \&$ 2. Yerevan: HSSR GA hratarakchutyun.

Ishkhanian, R. (1991). The Law of Excluding the Third Force. In G. J. Libaridian (Ed.) Armenia at the Crossroads. Democracy and Nationhood in the Post-Soviet Era. Blue Crane Books, Watertown, Mass.

Johannissjan, A. (2016). Israel Ori und die Armenische Befreiungsidee. Inagural-Dissertation zur Erlangung der Doktorwürde der Philosophischen Fakultät (1. Sektion) der K. LudwigMaximilians-Universität zu München vorgelegt von Aschot Johannissjan. In Hovhannisyan, A. (2016).
Israel Orin \& hay azatagrakan gaghapary' (Israel Ori and the Armenian Liberation Idea, in Armenian). Yerevan: Hovhannisyan institut.

Leo. (1934). Khojayakan kapitaly' \& nra qaghaqakan-hasarakakan dery' hayoc mej. Drvagner hay kgherakan divanagitut'yan patmut'yunic (The Merchant Capital and its PoliticalSocial Role for Armenians: Episodes from the History of Armenian Clerical Diplomacy, in Armenian) Vol. I. Yerevan: Pethrat.

Leo. (1994). T'urqahay heghap'okhut'yan gaghap 'arabanut'yuny' (The Ideology of the Turkish-Armenian Revolution, in Armenian). Vol. A. Yerevan: Shaghik.

Lyotard, J.-F. (1984).The Postmodern Condition. 1. Manchester University Press.

Nalbandian, M. (1985). Yerkragorc'ut'yuny' vorpes ughigh twanaparh (Agriculture as a Straight Way). In M. Nalbandian Collection of Works. Yerevan: Sovetakan grogh. 